\title{
Dampak Genangan Air Terhadap Keberadaan Beberapa Spesies Belalang (Orthoptera) di Ekosistem Persawahan
}

\author{
Ari Sugiarto \\ Email: sugiartoari13@gmail.com
}

\begin{abstract}
Abstrak
Terbentuknya genangan air di ekosistem persawahan pada musim hujan diperkirakan menyebabkan terjadinya perbedaan keberadaan beberapa spesies belalang dibanding pada akhir musim kemarau. Perlu dilakukan penelitian mengenai dampak genangan air terhadap keberadaan beberapa spesies belalang (Orthoptera) di ekosistem persawahan. Penelitian ini dilakukan pada bulan September sampai dengan Desember 2018 dengan mengamati beberapa spesies belalang di ekosistem persawahan pada akhir musim kemarau dan musim hujan. Hasil dari pengamatan menunjukkan adanya perbedaan keberadaan kondisi beberapa spesies belalang pada akhir musim kemarau dan musim hujan. Hal ini, dikerenakan pada musim hujan terbentuk genangan air yang menyebabkan tenggelamnya beberapa vegetasi sehingga menyebabkan vegetasi yang tumbuh menjadi berkelompok. Kondisi ini yang diperkirakan menyebabkan belalang beradaptasi terhadap adanya perubahan sehingga terjadi perbedaan keberadaan beberapa spesies belalang pada akhir musim kemarau dan musim hujan.
\end{abstract}

Kata kunci: Belalang, Ekosistem Persawahan, Genangan Air, Musim Kemarau dan Musim Hujan

\section{Pendahuluan}

Belalang (Orthoptera) lebih banyak terdapat di ekosistem persawahan dibandingkan pada ekosistem perkebunan (Sugiarto, 2018). Pola distribusi belalang pada suatu ekosistem salah satunya terkait dengan ketersediaan makan pada berbagai jenis vegetasi (Almeida dan Camara, 2008). Terjadinya perubahan musim kemarau ke musim hujan menyebabkan terjadinya transisi tanaman pada ekosistem persawahan (Heckman, 1979). Selain itu juga, adanya genangan air pada ekosistem persawahan akan membatasi pergerakan dari belalang, hal ini diperkirakan berdampak terhadap keberadaan beberapa spesies belalang pada ekosistem persawahan. Menurut Seino et al. (2013), belalang memiliki kepekaan terhadap gangguan pada suatu ekosistem. Perlu dilakukan penelitian mengenai dampak genangan air pada ekosistem persawahan terhadap keberadaan beberapa spesies belalang.

\section{Metode Penelitian}

Penelitian ini dilakukan pada bulan September sampai dengan Desember 2018. Metode penelitian ini dilakukan dengan melakukan pengamatan beberapa spesies belalang yaitu Atractomorpha crenulata, Gesonula mundata, Oxya Hyla, Phlaeoba fumosa, dan Xenocatantops humilis pada ekosistem persawahan. Menurut Sugiarto (2018), Atractomorpha crenulata, Gesonula mundata, Oxya Hyla, Phlaeoba fumosa, dan Xenocatantops humilis merupakan spesies belalang yang mudah untuk ditemukan pada ekosistem persawahan.

Pengamatan ini dilakukan pada penghujung musim kemarau (pasca panen) dan musim hujan, pengamatan ini dilakukan pada lokasi yang sama. Menurut Badan Meteorologi, Klimatologi dan Geofisika (2018), perkiraan awal musim kemarau tahun 2018/2019 di wilayah Indonesia umumnya dimulai pada bulan Mei dan Juni 2018, sedangkan musim hujan dimulai pada bulan Oktober sampai dengan Desember 2018. Pengamatan difokuskan 
pada keberadaan Atractomorpha crenulata, Gesonula mundata, Oxya Hyla, Phlaeoba fumosa dan Xenocatantops humilis di ekosistem persawahan sebelum adanya genangan air dan sesudah adanya genangan air. Hasil dari penelitian ini disajikan dalam bentuk paragraf deskriptif.

\section{Hasil dan Pembahasan}

Pengamatan keberadaan beberapa spesies belalang pada akhir musim kemarau didapatkan bahwa Atractomorpha crenulata dan Oxya Hyla keberadaannya tersebar pada tepian sampai ke tengah persawahan. Keberadaan kedua spesies belalang ini pada tepian persawahan tidak berada jauh dari batas bawah tepian. Phlaeoba fumosa dan Xenocatantops humilis keberadaannya berada pada tepian atas sampai melewati sedikit tepian bawah, namun tidak sampai kepertengahan persawahan. Gesonula mundata keberadaanya hanya pada persawahan saja, tidak sampai mendekati tepian bawah.

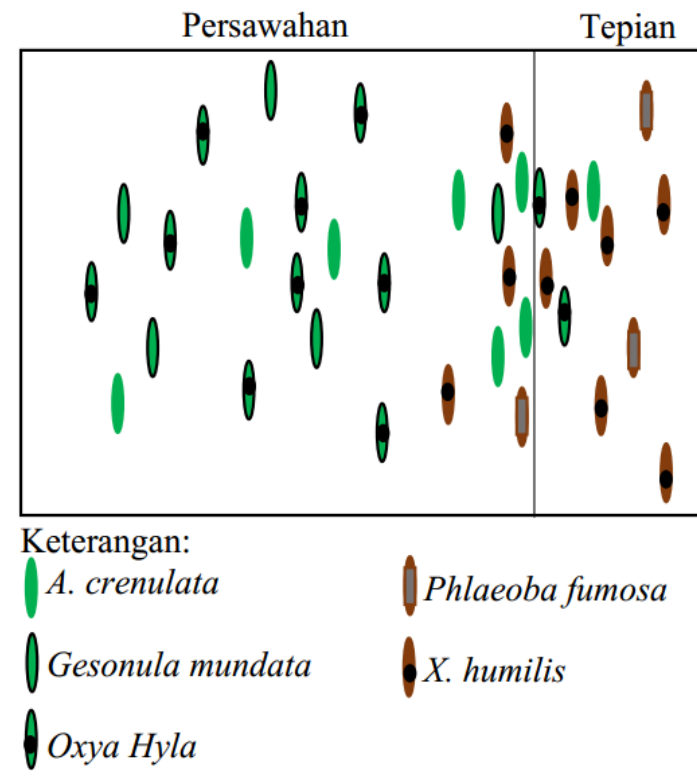

Gambar 1. Penggambaran keberadaan beberapa spesies belalang di ekosistem persawahan sebelum adanya genangan air.
Atractomorpha crenulata dan Oxya Hyla merupakan spesies belalang yang jumlah lebih banyak dibanding jumlah Gesonula mundata pada ekosistem persawahan, sedangkan Xenocatantops humilis jumlahnya lebih banyak dibanding Phlaeoba fumosa pada bagian tepian. Penggambaran keberadaan belalang pada akhir musim kemarau di ekosistem persawahan dapat dilihat pada Gambar 1 .

Pengamatan pada musim hujan, ketika ekosistem persawahan mulai tergenang air didapatkan Atractomorpha crenulata dan Oxya Hyla keberadaannya tersebar pada batas tepian bawah sampai ke tengah persawahan, sedangkan pada akhir musim kemarau keberadaan kedua spesies belalang ini tersebar dari tepian sampai ke tengah persawahan. Phlaeoba fumosa dan Xenocatantops humilis keberadaannya berada pada tepian, sedangkan di akhir musim kemarau keberadaan kedua spesies belalang ini dari tepian atas hingga melewati batas tepian bawah. Gesonula mundata keberadaanya hanya pada pertengahan persawahan, sedangkan di akhir musim kemarau keradaannya juga tersebar di dekat tepian. Penggambaran keberadaan belalang pada musim hujan di ekosistem persawahan setelah adanya genangan air dapat dilihat pada Gambar 2.

Tidak terlihat adanya perubahan jumlah belalang pada musim hujan dibanding dengan akhir musim kemarau. Atractomorpha crenulata dan Oxya Hyla jumlahnya tetap mendominasi dibanding spesies belalang lainnya pada persawahan, sedangkan pada bagian tepian Xenocatantops humilis jumlahnya tetap mendominasi. Pengamatan beberapa spesies belalang pada akhir musim kemarau dan musim hujan menunjukkan adanya perbedaan keberadaan beberapa spesies belalang pada ekosistem persawahan, hal ini diperkirakan merupakan adaptasi belalang terhadap perubahan yang terjadi pada ekosistem persawahan. Menurut Seino et al. (2013), belalang memiliki kepekaan terhadap gangguan pada suatu ekosistem. 


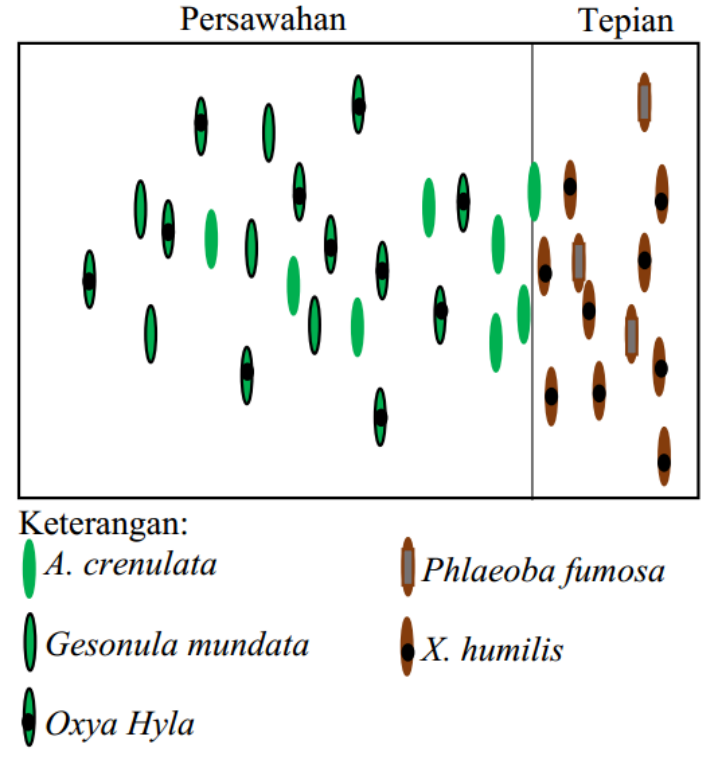

Gambar 2. Penggambaran keberadaan beberapa spesies belalang di ekosistem persawahan sesudah adanya genangan air.

Vegetasi tumbuhan pada akhir musim kemarau didominasi oleh semak dan rerumputan. Pada bagian tepian vegetasi semak mendominasi dibanding vegetasi rerumputan, sedangkan pada bagian persawahan vegetasi rerumputan mendominasi dibanding vegetasi semak. Di musim hujan juga didapatkan bahwa, vegetasi semak mendominasi pada bagian tepian dan vegetasi rerumputan mendominasi pada bagian persawahan. Perbedaan vegetasi musim kemarau dan musim hujan yaitu vegetasi yang tumbuh di akhir musim kemarau tersebar menyeluruh pada ekosistem persawahan, sedangkan vegetasi yang tumbuh pada musim penghujan tersebar berkelompok. Hal ini dapat disebabkan vegetasi yang tumbuh pada akhir musim kemarau tenggelam oleh genangan air di musim kemarau yang menyebabkan vegetasi yang tumbuh menjadi berkelompok. Selain itu juga, tumbuhan teratai, lotus, dan tumbuhan air lainnya juga mulai tumbuh pada musim hujan saat sudah terbentuk genangan air pada ekosistem persawahan. Menurut Heckman (1979), tumbuhan yang tumbuh pada saat ekosistem persawahan mulai tergenang air seperti Paspalum paspalodes, Echinochloa crus-galli, Cyperus iria, Cyperus polistachyos, dan Fimbristylis littoralis.

\section{Kesimpulan}

Pengamatan keberadaan beberapa spesies belalang di ekosistem persawahan pada akhir musim kemarau dan musim hujan menunjukkan adanya perbedaan keberadaan belalang, Hal ini, dikerenakan pada musim hujan terbentuk genangan air yang menyebabkan tenggelamnya beberapa vegetasi sehingga menyebabkan vegetasi yang tumbuh menjadi berkelompok. Kondisi ini yang diperkirakan menyebabkan belalang beradaptasi terhadap adanya perubahan sehingga terjadi perbedaan keberadaan beberapa spesies belalang pada akhir musim kemarau dan musim hujan.

\section{Daftar Pustaka}

Almeida, A.V dan Camara, C.A.G. 2008. Distribution of Grasshoppers (Othoptera: Acridoidea) in The Tapacurá Ecological Station (São Lourenço da Mata, PE / Brazil). Braz. J. Biol. 68(1): 2124.

Badan Meteorologi, Klimatologi dan Geofisika. 2018. Prakiraan Musim Hujan Tahun 20182019 di Indonesia. (Online). https://www.bmkg.go.id/berita/ ?p=prakiraan-musim-hujantahun-2018-2019-diindonesia\&lang $=$ ID\&s=detil.

Diakses pada tanggal 23 Desember 2018.

Badan Meteorologi, Klimatologi dan Geofisika. 2018. Prakiraan Musim Kemarau Tahun 2018 di Indonesia. (Online). https://www.bmkg.go.id/iklim/ prakiraan$\underline{\text { musim.bmkg? } p=11004 \& \operatorname{tag}=p}$ 
rakiraan-musim\&lang=ID.

Diakses pada tanggal 23

Desember 2018.

Heckman, C.W. 1979. Rice Field Ecology in Northeastern Thailand. Springer Science + Business, B.V.

Seino, R.A., Dongmo,T.I., Kekeunou, S., Chifon, R.N., dan Manjeli, Y. An inventory of short horn grasshoppers in the Menoua Division, West Region of Cameroon. Agriculture and
Biology Journal of North America. 4(3): 291-299.

Sugiarto, A. 2018. An Inventory of Grasshoppers (Orthoptera: Acrididae) in the Plantation and Rice Field Ecosystems of Serdang Menang Village, Sirah Pulau Padang Sub-district, Ogan Komering Ilir District. (Online).

https://osf.io/preprints/inarxiv/ hfxp9/. Diakses pada tanggal 24 Desember 2018. 